НАУКОВИЙ ВІСНИК

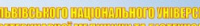

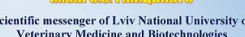

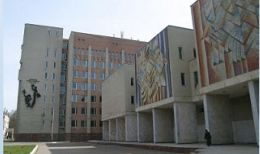

ERIES: VETERINARY SCIER
Науковий вісник Дьвівського національного університету ветеринарної медицини та біотехнологій імені С.3. Гжицького. Серія: Ветеринарні науки

Scientific Messenger of Lviv National University of Veterinary Medicine and Biotechnologies. Series: Veterinary sciences

UDC 619: 616.34: 616.98

\title{
Clinical case of associative course of panleukopenia and intestinal yersiniosis in cats
}

O. O. Truba, G. A. Zon

Sumy National Agrarian University, Sumy, Ukraine

Article info

Received 12.07.2021

Received in revised form 12.08 .2021

Accepted 13.08.2021

Sumy National

Agrarian University,

G. Kondratieva Str., 160,

Sumy, 40021, Ukraine.

Tel.: +38-098-649-03-41,

$+38-099-254-52-15$

E-mail: zon_g@ukr.net, truba8@ukr.net
Truba, O. O., \& Zon, G. A. (2021). Clinical case of associative course of panleukopenia and intestinal yersiniosis in cats. Scientific Messenger of Lviv National University of Veterinary Medicine and Biotechnologies. Series: Veterinary sciences, 23(103), 88-95. doi: 10.32718/nvlvet10312

The study of the course and manifestation of mixed infections is an important modern problem of both humane and veterinary medicine because their diagnosis is quite complex and time-consuming. The clinical manifestation of double and sometimes triple infection has its characteristics, which depend on various biotic and abiotic factors. To date, it has been proven that the associative course of several infectious diseases is registered more and more often, which confirms the case of simultaneous manifestation of panleukopenia and intestinal yersiniosis in domestic outbred cats. Diagnosis of mixed infection was comprehensive through general clinical and laboratory studies, the use of rapid test systems to confirm the diagnosis of panleukopenia and RNGA with specific yersinia antigens to determine the status of intestinal yersiniosis in cats. The latter was caused by serovar Y. enterocolitica $0: 9$ with a diagnostic titer of 1: 400. Thanks to microbiological studies, the causative agent of intestinal yersiniosis $Y$. enterocolitica was isolated. Its biological properties were determined, and antimicrobial sensitivity to enrofloxacin and doxycycline was established against the background of polyresistance to ceftriaxone and tetracycline. During treatment, it was found that the clinical case of intestinal yersiniosis was also due to the simultaneous infection of $Y$. enterocolitica with two types of serotypes O: 3 and O: 9. Which also have their own specific features. But in most cases, we have different sensitivity to antibacterial drugs, in contrast to the case we described. Clinical signs of the associated course of panleukopenia and intestinal yersiniosis in domestic outbred cats were characterized by prolonged diarrhea, streaks of blood and mucus, apathy, refusal to feed, general weakness. Therapeutic measures containing antibacterial drugs, energy sources, crystalloids, buffer infusions which were aimed at reducing dehydration and maintaining water-salt balance in the complex, were effective, clinical signs of the disease disappeared on the eighth day of treatment, and complete isolation of the pathogen in the environment ceased on the thirteenth day, which indicated the complete recovery of the animal. However, to prevent re-infection, it was recommended to treat disinfectants with care items and utensils. And also to avoid direct contact with animals that have pronounced clinical signs of disease. To prevent the occurrence of panleukopenia, scheduled mass vaccinations with mandatory observance of time limits.

Key words: intestinal yersiniosis of cats, Yersinia enterocolitica, associated course, panleukopenia, intestinal infections in cats, mix of infection, viral-bacterial association.

\section{Клінічний випадок асоціативного перебігу панлейкопенії та кишкового ісрсиніозу у кішки}

\author{
О. О. Труба, Г. А. Зон
}

Сумський національний аграрний університет, м. Суми, Україна

Вивчення перебігу та прояву змішаних інфекцій є важливою сучасною проблемою як гуманної, так $і$ ветеринарної медицини, адже їхня діагностика досить складна та довготривала. Клінічний прояв подвійної, а іноді й потрійної інфекиї, має свої особливості, які залежать від впливу різноманітних біотичних та абіотичних факторів. На сьогодні доведеним є той факт, щзо асоціа- 
тивний перебіг кількох інфекиійних захворювань реєструється все частіше, шо підтверджує і досліджений нами випадок одночасного прояву панлейкопенї̈ та кишкового ієрсиніозу в домашньої безпородної кішки. Встановлення діагнозу на мікст-інфекцію відбувалось комплексно шляхом загальних клінічних і лабораторних досліджень, застосування експрес-тест систем для підтвердження діагнозу на панлейкопенію і проведення РНГА зі специифічними ієрсиніозними антигенами для визначення статусу щзодо кишкових ієрсиніозів котів. Останній був викликаний сероваром Y. enterocolitica 0:9 з діагностичним титром 1:400. Завдяки проведеним мікробіологічним дослідженням вдалось ізолювати збудника кишкового ієрсиніозу Ү.ептегосодіtica, а також визначити його біологічні властивості та встановити антимікробну чутливість до енрофлоксацину $і$ доксицикліну на тлі полірезистентності до иефтриаксону та тетрацикліну. В ході лікування встановлено, щцо клінічний випадок кишкового ієрсиніозу був зумовлений ще й одночасним інфікуванням Y. еnterocolitica двома видами серотипів O:3 та О:9, які також мають свої специфічні ознаки та в більшості випадків різну чутливість до антибактеріальних препаратів, на відміну від описаного нами випадку. Клінічні ознаки асочійованого перебігу панлейкопенї та кишкового ієрсиніозу в домашньої безпородної кішки характеризувались, довготривалою діареєю, з прожилками крові та слизу, апатією, відмовою від корму, загальною слабкістю. Терапевтичні заходи, щя містили антибактеріальні препарати, препарати джерел енергії, кристалоїди, буферні розчини вливання яких було спрямоване на зниження дегідратаџї та підтримку водно-сольового балансу, в комплексі були ефективними, клінічні ознаки хвороби зникли на восьму добу від початку лікування, а повне виділення збудника в довколишнє середовище припинилось на тринадияту добу. Це й свідчило про повне одужання тварини. Та задля недопущення повторного зараження було рекомендовано обробляти дезінфектантами предмети догляду й посуд, а також уникати прямих контактів з тваринами, шо мають яскраво виражені клінічні ознаки хвороб. Для запобігання виникнення панлейкопенї- проведення планових, масових вакцинацій з обов 'язковим дотриманням часових меж.

Ключові слова: кишковий ієрсиніоз котів, Yеrsinia епterocolitica, асоційований перебіг, панлейкопенія, кишкові інфекції у котів, мікс інфекиії, вірусно-бактеріальна асоціація.

\section{Ветуп}

Останнім часом все частіше спостерігаються складні системні форми кишкових захворювань у котів. В багатьох випадках це пов'язано з асоціативним перебігом декількох захворювань. Нерідко реєструють асоціативний перебіг вірусних та бактеріальних хвороб, які є досить схожими за клінічним перебігом.

Вірусну панлейкопенію котячих (FPV) викликає парвовірус, що спричиняє ентерит та лейкопенію у домашніх та диких видів котів у всьому світі. Хвороба клінічно характеризується лихоманкою, млявістю, відсутністю апетиту, блювотою, діареєю, зневодненням, раптовою смертю. Іноді реєструють і неврологічну симптоматику.

Схожими клінічними ознаками у котів характеризується й бактеріальна інфекція - кишковий ієрсиніоз. В Україні це переважно спорадичне захворювання i змішані форми перебігу цієї інфекції з іншими патогенами спостерігаються доволі рідко.

Вважається, що недоліки в технології за масового виробництва товарів тваринного походження, розширення мережі дрібних фабрик з переробки м'яса, що мають складні ланцюги з холодильних камер, і міжнародна торгівля м'ясними продуктами та тваринами можуть сприяти поширеності ієрсиніозу серед людей. Також безпосередньо самі тварини, що перебувають поруч з людьми в країнах з низьким і середнім рівнем доходу, можуть містити безліч патогенів, які контамінують фекалії домашніх тварин і здатні за певних умов потрапити до людини. Серед таких патогенів кишковий ієрсиніоз та FPV (Steinel et al., 2001).

На прикладі клінічного випадку було досліджено змішаний перебіг двох інфекції. Досліджений нами клінічний випадок мав гострий перебіг середньої тяжкості і завершився повним зникненням клінічних ознак у пацієнта після семиденного курсу лікування. А видужання та припинення виділення збудника $Y$. enterocolitica настало на 13 день від початку лікування.

Поєднання двох патогенних агентів теоретично передбачає тяжчий клінічний перебіг з вираженою дегідратацією і необхідністю госпіталізації. А беручи до уваги те, як ротавіруси стимулюють адгезію і підсилюють інвазивний потенціал Yersinia enterocolitica, що своєю чергою призводить до ризику виникнення генералізованих форм ієрсиніозу, за якого клінічна картина може бути спотвореною, можна сказати, що даний випадок протікав легко та за класичною схемою подібних асоціацій. Вищеперелічене становить певний інтерес для клініцистів, а також додає певної інформації про асоціативні хвороби котячих.

В ході лікування встановлено, що клінічний випадок кишкового ієрсиніозу був зумовлений ще й одночасним інфікуванням $Y$. enterocolitica двома видами серотипів O:3 та O:9, які також мають свої специфічні ознаки.

Котячий вірус панлейкопенії (FPV) - парвовірус викликає ентерит та панлейкопенію у домашніх та диких видів котів (Steinel et al., 2001). Він також асоціюється $з$ хворобами єнотів, норок, лисиць та мавп і може розмножуватися у тхорів, не спричиняючи хвороби. Панлейкопенію котів іноді називають “котячою чумою”, що трапляється переважно у котів віком до 1 року, проте хворобу реєструють у невакцинованих або неправильно щеплених котів будь-якого віку. Спалахи панлейкопенії у котів сезонно корелюються. Хвороба найчастіше трапляється в закритих розплідниках тварин та притулках. Може перебігати в гострій, підгострій, блискавичній формах. В основному гострий перебіг більш характерний для дорослих тварин та супроводжується відмовою від їжі, апатією, діареєю, блювотою від жовтого до зеленого кольору, іноді зі слизом та включеннями крові. Підгостра форма перебігу більш характерна для щеплених тварин або для тварин зі стійким імунним захистом. При іiі перебігу всі симптоми змазані та не виражені. У кішок, які перехворіли на панлейкопенію, утворюється тривалий імунітет проти цієї інфекції, що передається разом з молоком майбутнім кошенятам і захищає їх від впливу вірусу протягом 10-12 тижнів після народження.

Досить схожим за перебігом є кишковий ієрсиніоз. 
Кишковий ієрсиніоз - гостре зооантропонозне захворювання, що викликається грамнегативною бактерією з роду Yersinia, яке характеризується ураженням шлунково-кишкового тракту, органів респіраторної системи, артритами, септікопіємією, безпліддям у самок, народженням нежиттєздатного молодняку. Інфекція проявляється у вигляді гострої діареї, мезентеріального адениту, термінального ілеїту (HernándezPorras et al., 2017). Відомо 76 серотипів Y. enterocolitica, 3 яких 11 спричинюють хворобу в людей та теплокровних тварин. Існує зв'язок між серогрупами та біоварами Yersinia enterocolitica та екологічним розповсюдженням патогенних штамів штамів людини, виділених переважно зі свиней, шиншил та зайців. Більш детальним дослідженням даного питання займаються вчені США та Японії.

Збудники ієрсиніозу $Y$. pseudotuberculosis та $Y$. enterocolitica трапляються у всьому світі, переважно в районах з помірним і субтропічним кліматом. За безсимптомного перебігу інфіковані теплокровні тварини тривалий час забруднюють навколишне середовище, що $є$ одним 3 найважливіших факторів епідеміології ієрсиніозу. Апатогенні та патогенні види Yersinia, значною мірою пристосовані до умов навколишнього середовища і незалежні від тепло- або холоднокровних організмів-господарів (Aleksić \& Bockemühl, 1990).

Проте хвороба може перебігати у важкій формі 3 прогресуючою дегідратацією, млявістю і розвитком ускладнень різного характеру. Збудник проявляє внутрішню стійкість до кількох антибіотиків, що ускладнює лікування хворих на кишковий ієрсиніоз.

Гастроентерит у котів також може бути наслідком кишкового ієрсиніозу, саме тому потрібна комплексна диференційна діагностика.

Світові епідеміологічні дані свідчать про те, що Y. enterocolitica поступово поширює свій ареал на різних континентах. А людина в ланцюзі передачі $€$ досить випадковим господарем, який не є необхідним для постійної підтримки чи передачі збудника.

Для собак і дрібних домашніх тварин найбільш патогенними вважають Yersinia enterocolitica та Yersinia pestis (Cully, 2010).

На думку багатьох практикуючих ветеринарних лікарів, у котів і собак $Y$. enterocolitica найчастіше клінічного прояву захворювання не викликає. Навіть $є$ припущення, що Yersinia enterocolitica $є$ природним кишковим комменсалом у котів, тому вони можуть бути безсимптомними носіями. Та його можна виділити від котів 3 хронічним перитонітом.

Найчастіше у котів виділяються біовари 2, 3, 4 та серотипи O:3 та O:9, вони є спільними і для людей. Та незважаючи на цей факт, досить мало інформації про частоту передачі ієрсиніозу між людьми, котами та собаками. Немає чітко встановленої причин виникнення інфекції, котрою може бути як контакт з зараженою твариною, так і прийом забрудненої їжі.

Поодинокі джерела вказують, що Yersinia enterocolitica - це залізозалежна бактерія, яка цілком спирається на екзогенне залізо для росту. I лікування синдромів перевантаження залізом хелатними агента- ми може спричинити ієрсиніоз, оскільки Yersinia enterocolitica може використовувати екзогенні сидерофори, такі як десферіоксамін, для отримання заліза. Перевантаження залізом та лікування хелатом заліза $€$ незалежними факторами ризику системного ієрсиніозу. Абсцеси печінки є типовою ознакою ієрсиніозу, пов'язаного 3 перевантаженням залізом або терапією десферіоксаміном, і майже завжди множинні за місцем розташування (Vadillo et al., 1994).

Лише у молодих тварин можуть розвиватися ознаки запального ураження кишечнику, в більшості випадків інкубаційний період становить 4-6 днів (діапа3он, 1-14 днів), і початок симптомів може бути поступовішим порівняно 3 інфекціями, викликаними іншими кишковими збудниками.

За існуючою інформацією, ієрсиніоз у котів проявляється у вигляді:

- запалення і набухання регіонарних лімфовузлів, особливо глоткових;

- лихоманки ;

- артритів;

- депресії та апатії;

- анорексії і полідипсії (тварина не їсть, але багато п'є);

- задишки через пневмонію (легенева форма, трапляється вкрай рідко);

- набряків;

- септичного шоку;

- порушення згортання крові.

Досить неоднозначним сигналом про наявність хвороби є реактивний артрит, що уражає п'ястки, колінні суглоби, плюсни та може проявлятися через місяць після першого епізоду незатяжної діареї (Klimov, 2017). I хоча Y. enterocolitica досить рідко викликає позакишкові захворювання, та все ж вони є. I у випадку позакишкового інфікування як спосіб передачі визначається прямий контакт. А тому є досить високий шанс повторного перезараження (Grahek-Ogden et al., 2007).

Діагностика ієрсиніозу залишається досить складною, хоча бактеріологічний посів проб калу (крові або інших біологічних матеріалів) вважається “золотим стандартом" діагностики, він є досить тривалим та трудомістким. Це пов'язано $з$ тим, що ентеропатогенні ієрсинії складно відрізнити від інших кишкових мікроорганізмів, які в нормі переважають у кишковій флорі. Крім того, деякі ієрсинії можуть бути присутніми в пулі автохтонної мікрофлори кишечнику. Після виявлення зростання рівня ієрсиній проводять додаткові відповідні тести, за якими встановлюють їх ентеропатогенність. Проте метод бактеріологічного посіву характеризується досить низькою чутливістю (для отримання результату необхідно 103-106 КУО в грамі зразка біоматеріалу). 3 огляду на ці особливості, діагностика ієрсиніозу повинна завжди бути комплексною і включати такі додаткові тести: полімеразну ланцюгову реакцію (ПЛР) та серологічні тести. Точність ПЛР і серологічних тестів $є$ досить високою навіть за умов отримання пацієнтом антибіотиків, на відміну від бактеріологічного методу, який в таких випадках може давати некоректний результат. Однак 
максимально точний результат тесту вдається отримати при аналізі біоматеріалу, одержаного до початку лікування.

Клінічно гастроентерит, що виникає при інфікуванні ентеропатогенними ієрсиніями, складно відрізнити від гастроентеритів за перебігу сальмонельозу, кампілобактеріозу, FIP та інших кишкових інфекцій. 3 цієї причини часто потрібні додаткові лабораторні аналізи.

У котів хвороба часто протікає значно важче, збудник викликає не тільки запалення тонкого і товстого відділів кишечника, а також вражає багато паренхіматозних внутрішніх органів. Втім, у цих випадках, найімовірніше, треба підозрювати хворобу, викликану Yersinia pestis (Klimov, 2017). Y. pestis - збудник бубонної (пневмонічної) чуми людини, спричиняє важке захворювання i y природних мешканців-гризунів, таких як миші, ховрахи, коти та собаки, проте в останніх хвороба може мати перебіг від легкого до безсимптомного (Cully, 2010). Котяча чума, викликана цим штамом, трапляється у багатьох країнах Африки, Європи та обох Америк. Гризуни, включаючи білок і лугових собачок, є природними господарями. Переносниками інфекції $€$ кровоссальні комахи, включаючи кліщів і бліх. Останні можуть залишитися зараженими протягом багатьох місяців. Після укусу інкубаційний період хвороби у кішки становить 26 днів, але після поїдання зараженого гризуна цей термін скорочується до одного-трьох днів. Збудник чуми утримується в ендемічних районах блохами (Perry \& Fetherston, 1997).

Вважається, що собаки та коти є тваринамиіндикаторами для нагляду за чумою, але прослідковується тенденція, що їх асоціація з людськими інфекціями є рідкістю (Wang, 2011). Після укусу інфікованої блохи підшкірні Y. pestis фагоцитуються тканинними нейтрофілами та макрофагами (Laws, 2010). Кішки виявляються більш схильними до розвитку захворювань порівняно з собаками (Gasper, 1993).

Патогенез інфекції FPV подібний до патогенезу інфекції кишкового ієрсиніозу. А саме: в обох хворобах передача відбувається фекально-оральним шляхом, а непряма передача через заражені фоміти, клінічна картина подібна діареєю та відмовою від корму.

Субклінічна інфекція широко поширена серед дорослих тварин.

Тяжкість захворювання залежить від таких факторів, як вік, імунний статус та паралельні інфекції з іншими бактеріальними збудниками, які збільшують швидкість обороту клітин епітелію кишечнику та посилюють руйнування самих клітин. Захворювання зазвичай виникає після інкубаційного періоду від 2 до 10 днів. Інфікування кошенят призводить до млявості, слабкості, швидкої втрати ваги, зникнення апетиту, діареї, дегідратації. Y. enterocolitica має ентеротоксин, дія якого подібна до ентеротоксинів інших грамнегативних мікроорганізмів і проявляється активацією аденілатциклази ентероцитів, підвищенням проникності їхніх мембран для води й електролітів, що обумовлює діарею аж до дегідратації (McNally et al., 2004). Спостерігається також збільшення рівня про- стагландину Е, чим підтверджується роль алергії в патогенезі захворювання (Shestakova et al., 2005).

Аборт, вроджені аномалії або безпліддя можуть бути наслідком зараження на ранніх термінах вагітності. Ступінь важкості перебігу захворювання може бути різним у тварин однієї вікової групи та статі.

Постановка проблеми: відсутність відомостей про асоціативний перебіг кишкового ієрсиніозу та панлейкопенії у котів.

3'вязок з державними науковими програмами. Дослідження $\epsilon$ фрагментом НДР кафедри вірусології, патанатомії та хвороб птиці Сумського НАУ "Удосконалення методів ранньої діагностики і лікувальнопрофілактичних заходів для запобігання емерджентних та економічно значущих хвороб тварин” (№ державної реєстрації 0118U100371).

Метою роботи було дослідити та описати клінічний випадок змішаної інфекції $Y$. enterocolitica і панлейкопенії у кішки.

\section{Матеріал і методи досліджень}

Усі маніпуляції з тваринами проводили відповідно до Європейської конвенції про захист хребетних тварин, які використовуються для експериментальних i наукових цілей (Official Journal of the European Union L276/33, 2010).

Дослідження містили збір анамнестичних, клінічних даних, біохімічні показники: глюкоза, сечовина, АЛТ, АСТ, креатинін, загальний білок, та гематологічні кількісні показники: лейкоцити, лімфоцити, моноцити, еритроцити, гемоглобін, ШОЕ; серологічні дослідження в ІФА, експрес діагностикум фірми Anigen Rapid FPV ag панлейкопенія кішок, РНГА з ієрсиніозними антигенами вітчизняного виробництва( ДП “Ветеринарна медицина” ННЦ “ІЕКВМ” УААН м. Харків) в основу якої покладена адсорбція антигенів на поверхні еритроцитів і подальша їх гемологічна аглютинація саме специфічного антигену сироваткою. Дана методика дозволяє виявити антитіла в більш ранні терміни, а також відрізняється досить високою чутливістю i специфічністю, адже застосовуються специфічні антигени.

Біохімічні дослідження проводили на напівавтоматичному біохімічному аналізаторі BS3000M. Для підрахунку гематологічних показників використовували ветеринарний гематологічний аналізатор Mindray BC-2800 Vet.

Бактеріологічні дослідження проводили шляхом посіву патологічного матеріалу на ієрсиніозне поживне середовище Yersinia selective agar base ТОВ “Фармактив”. Чутливість ізоляту Y. enterocolitica до антибіотиків визначали шляхом диско-дифузійного методу, який базується на властивостях антимікробних препаратів дифундувати із насичених паперових дисків в поживне середовище, при цьому пригнічувати ріст мікроорганізмів, що попередньо були засіяні на середовище. Отримані результати оцінювали шляхом встановлення діаметра зони затримки росту мікроорганізмів навколо диска. В нашому випадку ми визначали чутливість ізоляту $Y$. enterocolitica до ломефлок- 
сацину, тертацикліну, гентаміціну, ципрофлоксацину, метранідазолу, доксицикліну, амоксицілін з клауліновою кислотою, норфлоксацину, цефтриаксону, виробника ТОВ “Фармактив”.

Визначення чутливості встановлювали дискодифузійним методом та оцінювали результати за настановою виробника.

\section{Результати досліджень}

До ветеринарної клініки принесли кішку, трирічного віку метис, вагою 2,6 кг. При зборі анамнестичних даних було встановлено, що в перший рік життя тварині двічі провели щеплення проти панлейкопенії, кальцивірозу та ринотрахеїту, згідно з рекомендаціями, щорічній ревакцинації тварина не підлягала. Обробки проти екзо- та ендопаразитів проводилися регулярно (зі слів власника тварини). До цього тварина не мала тяжких та хронічних захворювань. Раціон тварини складала виключно натуральна їжа, додаткові вітамінно-мінеральні добавки не використовувались. Власник тварини з моменту захворювання спостерігав протягом чотирьох діб стійку діарею, відмову від звичного корму з другого дня виникнення хвороби, але ще декілька днів зберігався інтерес до комерційних консервованих кормів, після чого настала - повна відмова від їжі. У тварини реєстрували хитку ходу, малорухливість, блідість слизових оболонок.

Зі слів власника - тварина проходила курс терапії в іншій ветеринарній клініці в зв'язку з позитивним експрес-тестом на панлейкопенію. Діагноз встановили на основі даних анамнезу та проведеного експрестесту, додаткові клінічні дослідження та диференційна діагностика не проводились. Після симптоматичного лікування стан тварини не поліпшився, тому власники звернулись за додатковим обстеженням та лабораторними дослідженнями в іншу клініку ветеринарної медицини.

При клінічному обстеженні встановили таке. Температура тіла становила $39,8{ }^{\circ} \mathrm{C}$, слизові оболонки бліді. Присутній неприємний, різкий запах від тварини. При пальпації спостерігалася болючість в черевній порожнині, з локалізацією в анатомічних ділянках печінки та тонкого кишечнику. Дихання прискорене, поверхневе, дегідратація 6-9 \%, знесилення, кволість. Втрата еластичності шкіри, тьмяний шерстяний покрив.

В ході обстеження було відібрано кров для проведення клінічного та біохімічного дослідження, кал та мазки зі слизових оболонок на виявлення бактеріологічного обсіменіння та диференційної діагностики.

У результаті лабораторних досліджень було встановлено: анемію, лейкоцитоз, зниження рівня нейтрофілів в межах 2 \% від норми, зі зсувом вліво, решта показників були в межах норми (табл. 1).

Біохімічні дослідження виявили зростання рівня білірубіну(як загального, так і прямого), що свідчить про порушення функцій печінки (табл. 2). Решта показників були в межах норми.

Таблиця 1

Результати клінічного аналізу крові

\begin{tabular}{|c|c|c|c|c|c|}
\hline Показник крові & Одиниці виміру & Значення норми & Отримані показники & \multicolumn{2}{|c|}{ \% відхилення } \\
\hline Гематокрит & $\%$ & $26-48$ & 32,5 & & Норма \\
\hline Гемоглобін & г/л & $80-150$ & 46 & $\nabla$ & 44 \\
\hline Еритроцити & Т/л & $5,3-10$ & 5,2 & $\nabla$ & 0,1 \\
\hline ШOE & $\mathrm{MM} / \Gamma$ & $0-13$ & 4 & & Норма \\
\hline Лейкоцити & Г/л & $5,5-18,5$ & 18,7 & $\Delta$ & 1,3 \\
\hline Сигментоядерні нейтрофіли & $\%$ & $35-75$ & 34,2 & $\nabla$ & 2 \\
\hline Паличкоядерні нейтрофіли & $\%$ & $0-3$ & 2 & & Норма \\
\hline Лімфоцити & $\%$ & $20-55$ & 32 & & Норма \\
\hline Моноцити & $\%$ & $1-4$ & 1 & & Норма \\
\hline Базофіли & $\%$ & поодинокі & 2 & & Норма \\
\hline Тромбоцити & $\times 10^{3} / \pi$ & $300-630$ & 430 & & Норма \\
\hline
\end{tabular}

Таблиця 2

Результати біохімічного аналізу крові

\begin{tabular}{lccc}
\hline \multicolumn{1}{c}{ Показники } & Одиниці виміру & Значення в нормі & Отримані показники \\
\hline Глюкоза & ммоль/л & $3,2-6,4$ & 5,48 \\
Сечовина & ммоль/л & $5,4-12,1$ & 6,7 \\
Креатинін & ммоль/л & $70-165$ & 78,7 \\
АлАТ & Од & $19-79$ & 39,2 \\
АсАТ & Од & $9-29$ & 22,1 \\
Загальний білірубін & мг/л & $0,1-4$ & \multicolumn{1}{c}{19} \\
Прямий білірубін & мг/л & $0-3$ & $\Delta, 2$ \\
Альбумін & г/л & $25-37$ & \\
\hline
\end{tabular}

При проведенні додаткових досліджень сироваток крові на маркери вірусних гепатитів отримали негативні результати. 3 метою диференційної діагностики
Y. enterocolitica від $Y$. pestis, Y. pseudotuberculosis була проведена РНГА, в ході якої встановили титр антитіл в парних сироватках крові 3 ієрсиніозними 
антигенами вітчизняного виробництва до Yersinia enterocolitica O:3 та O:9, а в реакції аглютинації (при діагностичному титрі 1:200) становив 1:400 (до Y. enterocolitica 0:9 ) та 1:200 до Y. enterocolitica 0:3. Також повторно був проведений експрес-тест FPV дав позитивний результат.
На підставі аналізу анамнестичних та клінічних даних та результатів лабораторних досліджень був встановлений діагноз - асоціативний перебіг кишкового ієрсиніозу та панлейкопеніі.

Результати визначення чутливості ізоляту ієрсинії до антибіотиків диско-дифузійним методом наведено в таблиці 3 .

\section{Таблиця 3}

Результати визначення чутливості Y.enterocolitica до антибіотиків

\begin{tabular}{|c|c|c|c|}
\hline Антибіотики & Високочутлива & чутлива & нечутлива \\
\hline \multicolumn{4}{|l|}{ Пеніциліни: } \\
\hline Амоксицилін з клавулановою кислотою & & & + \\
\hline \multicolumn{4}{|l|}{ Цефалоспорини: } \\
\hline Цефтриаксон & & & + \\
\hline \multicolumn{4}{|l|}{ Аміноглікозиди: } \\
\hline Гентаміцин & + & & \\
\hline \multicolumn{4}{|l|}{ Макроліди: } \\
\hline Ципрофлоксацин & + & & \\
\hline Енрофлоксацин & + & & \\
\hline \multicolumn{4}{|l|}{ Тетрацикліни: } \\
\hline Доксицилін & & + & \\
\hline Тетрациклін & & & + \\
\hline
\end{tabular}

За даними таблиці 3 , збудник кишкового ієрсиніозу був нечутливим до амоксициліну 3 клавуліновою кислотою, тетрацикліну та цефтриаксону та високочутливим до доксицикліну, гентаміцину, ципрофлоксацину та енрофлоксацину. Тому препаратом вибору для лікування тварини було обрано саме енрофлоксацин. Крім цього, було застосовано імуностимулюю- чу (максидин) та підтримуючу терапії (дуфалайт), вітамінотерапію (гепавікел) і дієтотерапію.

Результати терапевтичних заходів наведено в таблиці 4.

Результати клінічних досліджень наведені в таблиці 5.

\section{Таблиця 4}

Терапевтичний протокол лікування кішки за асоціативного перебігу кишкового ієрсиніозу та панлейкопенії

\begin{tabular}{|c|c|c|c|c|}
\hline Вид терапії & Препарат/дієта & $\begin{array}{l}\text { Доза на } 1 \text { кг } \\
\text { м. т./голову }\end{array}$ & $\begin{array}{c}\text { Кратність дозування/метод } \\
\text { введення }\end{array}$ & $\begin{array}{l}\text { Термін лікування, } \\
\text { діб }\end{array}$ \\
\hline Імуностимулююча & Максидін 0,4 & 0,5 до 5 кг & $\begin{array}{l}\text { внутрішньом’язово або } \\
\text { підшкірно } 2 \text { рази на добу }\end{array}$ & 5 \\
\hline Етіотропна & Енрофлоксацин -50 мг & 0,1 мл/кг & 1 раз/добу, підшкірно & 7 \\
\hline $\begin{array}{l}\text { Симптоматична, } \\
\text { підтримуюча }\end{array}$ & Дуфалайт & 30 мл & $\begin{array}{l}\text { внутрішньовенно, } \\
\text { краплинно, повільно }\end{array}$ & $\begin{array}{c}1 \text { раз/добу до зменшення } \\
\text { дегідратації }\end{array}$ \\
\hline Вітамінотерапія & Гепавікел & 0,1 мл/кг & підшкірно & $\begin{array}{c}1 \text { раз на добу з } 4 \text { дня } \\
\text { лікування на } 5 \text { введень }\end{array}$ \\
\hline Дегідратаційна & Реосорбілакт & 6 мл/ кг & $\begin{array}{l}\text { внутрішньовенно, } \\
\text { краплинно }\end{array}$ & $\begin{array}{c}1 \text { раз/добу не більше ніж } \\
3 \text { доби }\end{array}$ \\
\hline Дієтотерапія & $\begin{array}{c}\text { Royal Canin gastro intestinal } \\
\text { за добовою нормою } \\
\text { (залежно від маси тварини) }\end{array}$ & 5-6 раз/добу & орально & до 14 днів \\
\hline
\end{tabular}

\section{Таблиця 5}

Ефективність запропонованої схеми лікування кішки за кишкового ієрсиніозу, асоційованого з панлейкопенією

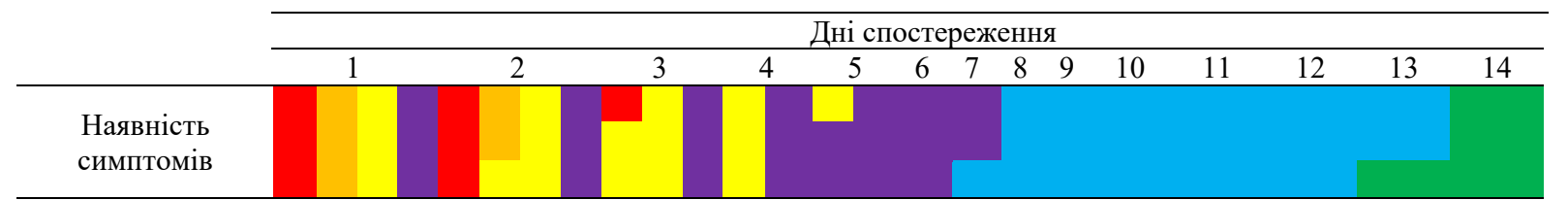

Примітка: наявність симптомів: $\square$ - мелена; $\square$ - блювання (не більше 2 разів на добу); $\square$ - дегідратація/ відмова від їжі;

$\square$ - слабкість ходи; $\square$ - відсутність клінічних ознак; $\square$ - припинення виділення збудника 
3 перших днів лікування тварині застосована комплексна терапія, що містила: антибактеріальний препарат - енрофлоксацин (до якого встановлена висока чутливість збудника ієрсиніозу), це дало позитивний результат вже на другу добу його використання. В другій половині дня тварина мала більш природний колір калу, який був сформований та не містив слизу і неперетравлених залишків їі. Та все ж спостерігалась періодична (не більше двох разів на добу) блювота, яка була спровокована великою кількістю випитої води і містила в своєму складі слиз, шлунковий сік та вкраплення крові. 3 урахуванням цього протиблювотні препарати не використовували, а тварині обмежили вільний доступ до води та випоювали пї по 2 мл раз на декілька години. Завдяки цьому вже на третю добу лікування блювота повність припинилася, та все ж відмова від їжі тривала до шостого дня включно, тому тварині вводили підтримуючі препарати.

На п'яту добу лікування у тварини з'явився апетит, тому для відновлення травлення було призначено ветеринарну дієту фірми Royal Canin gastro intestinal згідно з настановою виробника.

Слабкість ходи та зниження загальної активності зникло тільки на сьомий день від початку лікування. 3 восьмого дня в тварини були відсутні всі клінічні симптоми обох хвороб, але збудник Yersinia enterocolitica виділявся до 13 дня.

По закінченні лікування власникам тварини було рекомендовано провести повторні дослідження на виявлення ієрсиніозної інфекції через один місяць 3 метою контролю та недопущення повторного інфікування через предмети побуту.

\section{Обговорення}

Узагальнюючи результати отриманих даних, можна говорити про те, що даний випадок захворювання на кишковий ієрсиніоз кішки трапився на фоні панлейкопенії, що підтверджено проведеними клінічними та лабораторними дослідженнями (позитивний експрес-тест на FPV, клінічні та біохімічні показники крові, ізоляція збудника кишкового ієрсиніозу, позитивні серологічні реакції).

Діагностика кишкових хвороб у котів $\epsilon$ досить складною та довготривалою і не може базуватися тільки на одному методі дослідження. Для ізоляції збудника були розроблені процедури збагачення та селективні середовища, в яких мікроорганізми ідентифікуються за допомогою біохімічних реакцій і можуть бути диференційовані серологічними та, у випадку Y. enterocolitica, також методами фаготипізації. Диференціація патогенних та апатогенних штамів має діагностичне значення і повинна проводитися регулярно; для цього доступні прості тести. Демонстрація антитіл проти асоційованих із клітинною стінкою (ліпополісахарид) або кодованих плазмідами (білків) антигенів може підтвердити діагноз, якщо збудників не вдалося виділити. Ізоляція збудника дозволяє встановити його чутливість до антибактеріальних препаратів, що суттєво може вплинути на якість та терміни лікування.
В описаному випадку перше тестування на FPV дало позитивний результат, а додаткові тестування проведені не були, тому можна сказати, що первинний діагноз базувався тільки на експрес-тесті. А оскільки диференційна діагностика повною мірою не проводилась, не можна точно стверджувати про першочергову самостійність перебігу панлейкопенії.

Звертаючи особливу увагу на те, що тварині з перших днів хвороби була застосована антибактеріальна та імуностимулююча терапія, можна припустити, що саме цей факт і став вирішальним за досить легкого перебігу хвороби. А враховуючи можливу полірезистентність $Y$. enterocolitica до певних видів антибіотиків, можна припустити, що при використанні антибіотикотерапії препаратом вибору міг бути один 3 таких резистентних препаратів, що могло спричинити бактеріостатичну дію. На тлі пригнічення імунної системи вірусним агентом відбулась активізація септичного процесу та формування мікст-інфекції.

Видалення та утилізація фекалій $з$ навколишнього середовища зменшує поширення інфекції на інших тварин і людей. Власникам тварин було запропоновано здійснювати активну дезинфекцію предметів догляду, щоб обмежити можливу контамінацію збудником кишкового ієрсиніозу не тільки тварин, а й людей.

\section{Висновки}

1. Встановлено клінічний випадок захворювання на вірусно-бактеріальну асоціацію збудників панлейкопенії та кишкового ієрсиніозу у домашньої кішки, що характеризувалося досить легким перебігом за яскравої клінічної картини.

2. Кишковий ієрсиніоз був зумовлений одночасним інфікуванням Y. enterocolitica серотипів O:3 та O:9. Діагноз на інфекційну панлейкопенію було веріфіковано за клінічними та лабораторними дослідженнями.

3. Запропонована комплексна терапія кішки, хворої на асоціативний перебіг кишкового ієрсиніозу 3 інфекційною панлейкопенією, що містила енрофлоксацин, максидин, дуфалайт, гепавікел, на фоні дієтотерапії була ефективною.

Подальші дослідження планується спрямувати на виявлення закономірностей асоціативного перебігу кишкового ієрсиніозу котів з іншими хворобами.

Подяка. Висловлюємо подяку за допомогу у проведенні клінічних та біохімічних досліджень працівникам та керівнику клініки “Акула”, зооволонтерам.

\section{Відомості про конфлікт інтересів}

Автори стверджують про відсутність конфлікту інтересів.

\section{References}

Aleksić, S., \& Bockemühl, J. (1990). Microbiology and epidemiology of Yersinia infections. Immun Infekt., 18(6), 178-85. URL: https://pubmed.ncbi.nlm.nih.gov/2076900. 
Alonso, J. M. (1999). Interactions écologiques des Yersinia au sein de l'hôte réservoir commun, le rongeur [Ecological interactions among Yersinia in their common reservoir, the rodent]. Bull Soc Pathol Exot., 92(5 Pt 2), 414 417. URL: https://pubmed.ncbi.nlm.nih.gov/11000952.

Cully, J. F. (2010). The disease limits populations: plague and black-tailed prairie dogs. Vector Borne Zoonotic Dis. 10(1), 7-15. doi: 10.1089/vbz.2009.0045.

Gasper, P. W. (1993). Plague (Yersinia pestis) in cats: a description of the experimentally caused disease. J. Med Entomol., 30(1), 20-26. doi: 10.1093/jmedent/30.1.20.

Grahek-Ogden, D., Schimmer, B., Cudjoe, K. S., Nygard, K., \& Kapperud G. (2007). Outbreak of Yersinia enterocolitica serogroup 0:9 infection and processed pork, Norway. Emerging Infectious Diseases, 13(5), 754-756. doi: 10.3201/eid1305.061062.

Hernández-Porras, E. E., Rosero-Torres, L. E., ParraBarrera, E. L, Guerrero-Montilla, J. A., Gómez-Rubio, A. L., Moreno, J. (2017). Outbreaks of foodborne diseases studied by molecular methods. J. Rev. Salud Publica, 19(5), 671-678.

Klimov, A. (2017). Iersinioz u sobak i koshek: klinicheski projavlenija, diagnostika, lechenie. URL: https://vashipitomcy.ru/publ/sobaki/bolezni/iersinioz_ u_sobak_i_koshek_klinicheski_projavlenija_diagnosti ka lechenie/26-1-0-1688 (in Russian).

Laws, T. R. (2010). Neutrophils are important in early control of lung infection by Yersinia pestis. Microbes Infect., 12(4), 331-335. doi: 10.1016/j.micinf.2010.01.007.

McNally, A., Cheasty, T., Fearnley, C., Dalziel, R. W., Paiba, G. A., Manning, G., \& Newell, D. G. (2004).
Comparison of the bio- types of Yersinia enterocoliti$c a$ isolated from pigs, cattle and sheep at slaughter and from humans with yersiniosis in Great Britain during 1999-2000. Lett Appl. Microbiol, 39(1), 103-108. doi: 10.1111/j.1472-765X.2004.01548.x.

Perry, R. D., \& Fetherston, J. D. (1997). Yersinia pestisetiologic agent of plague. Clin. Microbiol. Rev, 10(1), 35-66. URL: https://www.ncbi.nlm.nih.gov/pmc/ articles/PMC172914.

Shestakova, I. V., Jushchuk, N. D., \& Andreev, I. V. (2005). $\mathrm{O}$ formirovanii immunopatologii u bol'nyh ersiniozom. Terapevticheskij arhiv, 11, 7-10 (in Russian).

Steinel, A., Parrish, C. R., Bloom, M. E., \& Truyen, U. (2001). Parvovirus infections in wild carnivores. Journal of Wildlife Diseases, 37(3), 594-607. doi: 10.7589/0090-3558-37.3.594.

Vadillo, M. N., Corbello, X., Pac, V., FernandezViladrich, P., \& Pujol, R. (1994). Multiple liver abscesses due to Yersinia enterocolitica discloses primary hemachromatosis: three case reports and review. Clinical Infectious Diseases, 18(6), 938-941. doi: 10.1093/clinids/18.6.938.

Wang, H. (2011). A dog-associated primary pneumonic plague in Qinghai Province, China. Clin. Infect. Dis., 52(2), 185-190. doi: 10.1093/cid/ciq107.

Zon, H. A., Ivanovska, L. B., \& Petrov, R. V. (2020). Metodychni rekomendatsi z diahnostyky kyshkovoho iiersyniozu dribnykh domashnikh tvaryn, Sumy (in Ukrainian). 